patients currently requesting fetal karyotyping can be counselled in favour of early testing if nuchal translucency is present as their risk is dramatically increased. Those without fetal nuchal translucency can be counselled that their background risk is reduced and consequently that they may prefer to have later amniocentesis, which may be safer, or to avoid invasive testing altogether.

1 Azar GB, Snijders RJM, Gosden C, Nicolaides KH. Fetal nuchal cystic hygromata: associated malformations and chromosomal defects. Fetal Diagn Ther. In press.

2 Nicolaides KH, Azar GB, Snijders RJM, Gosden C. Fetal nuchal edema: associated malformations and chromosomal defects. Fetal Diagn Ther. In press.

3 Byrne D, Marks K, Azar G, Nicolaides K. Randomized study of early amniocentesis versus chorionic villus sampling at 10-13 weeks' gestation: technical and cytogenic comparison of 650 patients. Ultrasound in Obstetrics and Gynecology 1991;1:234-40.

4 Van der Putte SCJ. Lymphatic malformation in human fetuses. Virchows Arch [A] 1977;376:233-46.

Nicolaides KH, Rodeck CH, Lange I, Watson J, Gosden CM, Miller D, et al.
Fynaecol 1985;92:671-9. Gustavii B, Edvall $\mathrm{H}$. Acta Obstet Gynecol Scand 1984;63:377-8. . Arenatal diagnosis of recurrence of cystic hygroma with normal chromosomes. Prenat Diagn 1984:4.383-6.

8 Reuss A, Pijpers L, Schampers PTFM, Wladimiroff JW, Sachs ES. The importance of thorionic villus sampling after first trimester diagnosis of cystic hygroma. Prenat Diagn 1987;7:299-301.

9 Reuss A, Pijpers L van Swaaij E, Jahoda MGJ, Wladimiroff JW. Firsttrimester diagnosis of recurrence of cystic hygroma using a transvaginal ultrasound transducer. Case report. Eur $\mathcal{f}$ Obstet Gynecol Reprod Biol 1987;26:271-3.

10 Pons JC, Diallo AA, Eydoux P, Rais S, Doumerc S, Frydman R, Papiernik E. Chorionic villus sampling after first trimester diagnosis of fetal cystic hygroma colli. Eur f Obstet Gynecol Reprod Biol 1989;33:141-6.

11 Bronshtein $M$, Rottem S, Yoffe N, Blumenfeld Z. First trimester and early second trimester diagnosis of nuchal cystic hygroma by transvagina sonography: diverse prognosis of the septated from the non-septated lesion. Am f Obstet Gynecol 1989;161:78-82.

12 Cullen MT, Gabrielli S, Green JJ, Rizzo N, Mahoney MJ, Salafia C, et al. Diagnosis and significance of cystic hygroma in the first trimester. Prenat Diagn 1990;10:643-51.

(Accepted 13 fanuary 1992)

\title{
Predictive diagnosis of familial adenomatous polyposis with linked DNA markers: population based study
}

\author{
F MacDonald, D G Morton, P M Rindl, J Haydon, R Cullen, J Gibson, J P Neoptolemos, \\ M R B Keighley, C M McKeown, M Hultén
}

\section{Abstract}

Objectives-To evaluate the use of polymorphic DNA probes linked to the APC gene in the presymptomatic diagnosis of familial adenomatous polyposis.

Design-Four DNA probes were tested on an unselected population of patients at risk of familial adenomatous polyposis.

Subjects-The first 47 families notified to the West Midlands familial adenomatous polyposis register. Plus five families sent to our hospital as part of the West of Britain DNA consortium.

Main outcome measures-The proportion of families and family members in whom DNA testing could be used to adjust the estimate of risk.

Results - Only 17 families on the register (containing $46 \%(74 / 162)$ of the population at risk) had a suitable pedigree structure for DNA analysis. DNA was analysed in 12 of these families plus the five families from the West of Britain consortium. At least one probe was informative in 27 of the 33 subjects born with $50 \%$ risk, but the most informative probe $(\pi 227)$ was the one with the highest recombination rate $(10 \%)$. Flanking markers were informative in only four of the 33 subjects.

Conclusions - These findings confirm the potential for accurate predictive diagnosis of familial adenomatous polyposis with polymorphic DNA probes, but such an approach is currently limited to about one third of affected families. A combined approach to presymptomatic diagnosis, which includes DNA testing and indirect ophthalmoscopy, is advocated.

\section{Introduction}

Familial adenomatous polyposis is an autosomal dominant condition which shows almost complete penetrance and occurs at a frequency of 1:10000 births. ${ }^{1}$ Up to $40 \%$ of cases are new mutations. ${ }^{2}$ The condition is characterised by the presence of hundreds or even thousands of adenomatous polyps throughout the colon and rectum, at least one of which is certain to progress to malignancy. ${ }^{3}$ Children of affected people are at $50 \%$ risk of inheriting the defective gene and developing the condition. As the age of onset of colonic polyps is variable it is recommended that people at risk are screened by repeated bowel examination from puberty until at least 40 years of age. ${ }^{2}$

A predictive test that is informative before the development of polyps could improve surveillance of those at high risk and reduce the frequency of, or eventually eliminate the need for, bowel examination in those at low risk. Such tests include indirect ophthalmoscopy to detect the presence of congenital hypertrophy of the retinal pigment epithelium ${ }^{4}$ or a DNA based test using markers linked to the causative gene (APC).

After a cytogenetically detectable deletion in chromosome 5 was observed in a mentally retarded man with familial adenomatous polyposis, the disease was mapped to 5q21-22 by the polymorphic marker C11p11. ${ }^{56}$ Several other polymorphic markers, including $\pi 227$ and YN5.48, have subsequently been identified $^{78}$ and a high resolution map identifying the position of these and other markers relative to the APC gene, has been described. ${ }^{9}$

The potential of these markers for diagnosis of familial adenomatous polyposis before symptoms emerge has been shown, but their clinical value was limited. C11p11 was relatively uninformative because one of the two alleles recognised by the probe was rare in the population. By contrast, $\pi 227$ was highly polymorphic but its use was limited because of its relatively high recombination rate. Recombination occurs due to crossing over of homologous chromosomes during meiosis, and the recombination rate of two markers is a measure of the genetic distance between them. In the case of $\pi 277$ this is $10 \%$. YN5.48 was the first linked marker to be localised to the telomeric side of the APC gene. ${ }^{10}$ This meant that the accuracy of diagnosis could be increased to close to $100 \%$ if both YN5.48 and one of the markers on the centromeric side of the gene were informative. When markers exist on both sides of the gene (flanking markers) inheritance can be highly accurately predicted as the occurrence of a recombination event can be positively identified in a patient in whom both markers are informative. 
A recent study of six families showed that flanking markers for familial adenomatous polyposis were informative in $68 \%$ of people at risk. ${ }^{11}$ Solomon recently suggested that the probes should be informative in most families. ${ }^{12}$

Up to now the presymptomatic diagnosis of familial adenomatous polyposis by linked probes has been applied to selected families who, because of a suitable pedigree, were amenable to linkage analysis. Linkage analysis will not be possible in some families either because affected family members died before storage of DNA or because of new mutations in the APC gene resulting in an isolated affected patient with no family history. Thus it may prove to be a minority, rather than a majority, of families who can benefit from polymorphic probe analysis. It is therefore important to evaluate the usefulness of DNA testing in all affected families within a defined population. We report the results of such a population based study covering the West Midlands Regional Health Authority.

\section{Subjects and methods}

A regional register for familial adenomatous polyposis was established in the West Midlands in 1988 jointly by our surgery and clinical genetics departments. Forty seven families with histologically proved familial adenomatous polyposis were notified to the register before June 1990 . Seventy two living affected subjects and 162 subjects born with $50 \%$ risk were identified. Subjects' current risk was based on age and

TABLE I-Details of probes used to detect familial adenomatous polyposis

\begin{tabular}{lcc}
\hline Probe & $\begin{array}{c}\text { Restriction fragment } \\
\text { length polymorphism } \\
\text { recognised }\end{array}$ & $\begin{array}{c}\text { Likelihood of recombination } \\
\text { occurring in between probe } \\
\text { and gene sites }\end{array}$ \\
\hline$\pi 227$ & Bc11, Pst 1^ & $10 \%$ \\
C11p11 & Taq1 & $7 \%$ \\
ECB27 & Bgl11 & $4 \%$ \\
YN5.48 & Mspl & $3 \%$ \\
\hline
\end{tabular}

^Two other polymorphisms are detected with this probe but have not provided additional information in our families.

TABLE II-Details of families affected by familial adenomatous polyposis notified to West Midlands register

\begin{tabular}{|c|c|c|c|c|}
\hline & \multirow{3}{*}{$\begin{array}{l}\text { No of } \\
\text { families }\end{array}$} & \multicolumn{3}{|c|}{ No of people } \\
\hline & & \multicolumn{2}{|c|}{ Affected } & \multirow[b]{2}{*}{ At risk } \\
\hline & & Alive & Deceased & \\
\hline \multicolumn{5}{|l|}{$\begin{array}{l}\text { All family members } \\
\text { affected or at risk }\end{array}$} \\
\hline $\begin{array}{l}\text { Possible new mutations } \\
\text { Incomplete pedigrees (key }\end{array}$ & 10 & 9 & 6 & 26 \\
\hline $\begin{array}{l}\text { family members dead) } \\
\text { Pedigrees suitable for }\end{array}$ & $15^{\star}$ & 17 & 19 & 62 \\
\hline DNA analysis & 17 & 46 & 10 & 74 \\
\hline Total & 47 & 72 & 40 & 162 \\
\hline
\end{tabular}

*Twenty eight deaths from colorectal cancer occurred before notification to the register and before DNA was stored.

TABLE III - Results of DNA analysis in patients with familial adenomatous polyposis and family members born with $50 \%$ risk

\begin{tabular}{lccccc}
\hline & \multicolumn{2}{c}{ Affected patients } & & \multicolumn{2}{c}{ Patients at risk } \\
\cline { 2 - 3 } \cline { 5 - 6 } Probe & $\begin{array}{c}\text { No of patients } \\
\text { tested }\end{array}$ & $\begin{array}{c}\text { No (\%) for whom } \\
\text { probe was informative }\end{array}$ & $\begin{array}{c}\text { No of patients } \\
\text { tested }\end{array}$ & $\begin{array}{c}\text { No (\%) for whom } \\
\text { probe was informative }\end{array}$ \\
\hline$\pi 227$ & 42 & $25(60)$ & & 33 & $22(66)$ \\
C11p11 & 42 & $9(21)$ & & 33 & $8(24)$ \\
ECB27 & 38 & $12(32)$ & & 25 & $2(11)$ \\
YN5.48 & 42 & $19(45)$ & & 33 & $7(21)$ \\
Flanking markers & 42 & $19(45)$ & & 33 & $4(12)$ \\
Any probe & 42 & $40(95)$ & & 33 & $27(94)$ \\
\hline
\end{tabular}

time of last negative result on sigmoidoscopy by using published age dependent penetrance figures. ${ }^{13}$ Those who had not had bowel examination were classified as having a $50 \%$ risk.

Paternity was checked by using four single locus hypervariable probes in those families in whom a recombination event was apparent. Otherwise during counselling we emphasised to all families that correct paternity was essential to the interpretation of the DNA results.

Probes-We used four probes linked to the APC locus that were available at the start of the study. Four probes were used to maximise the number of families who would be informative as well as to provide information with flanking markers if at all possible. Table I shows the restriction fragment length polymorphisms recognised by these probes and the risk of recombination occurring in between the probe and the APC gene sites, taken from published results. ${ }^{10} 11$ The presumed order of the location of the probes on chromosome 5 was (from centromere to telomere) $\pi 227, \mathrm{C} 11 \mathrm{p} 11, \mathrm{ECB} 27, \mathrm{APC}, \mathrm{YN} 5.48 .^{9}$

DNA studies - A blood sample $(10-20 \mathrm{ml})$ was taken from all available family members and DNA was purified from peripheral blood leucocytes. ${ }^{14} \mathrm{We}$ digested $10 \mu \mathrm{g}$ of DNA with the appropriate restriction enzymes; fragments were separated according to size by agarose gel electrophoresis and transferred to nylon membranes by standard procedures. ${ }^{14}$ These membranes were then hybridised to probes previously radiolabelled with phosphorus-32 by the random primer technique. ${ }^{15}$ Filters were subsequently washed to a stringency of $0.1 \times \mathrm{SSC}(150 \mathrm{mM}$ sodium chloride/ $15 \mathrm{mM}$ sodium citrate, $\mathrm{pH} 7 \cdot 0)$ and autoradiography was done at $-70^{\circ} \mathrm{C}$ for $24-96$ hours to reveal the position of polymorphic bands.

\section{Results}

Of the first 47 families referred to the register, 30 were unsuitable for analysis by DNA probes (table II). Twelve of the remaining 17 families, along with five families from outside our region, were tested with all four probes. The five other suitable families from the West Midlands were not tested: one family had only just become suitable for analysis, blood samples were awaited from two families, and two families were under investigation at other centres.

The DNA of 42 affected subjects was analysed to determine if the probes would be informative for presymptomatic diagnosis in their children. At least one of the probes was informative in 40 affected subjects, but in 25 the only informative probe was $\pi 227$. Flanking markers were informative in slightly less than half the affected individuals (table III).

The 12 families from the West Midlands register with suitable pedigrees for DNA analysis contained 54 subjects born with $50 \%$ risk of developing familial adenomatous polyposis. Eighteen of these were under 10 years of age, below the age at which bowel screening would be initiated, and thus were not screened; four subjects were over 50 years old and asymptomatic so again DNA testing was not done. Of the remaining 32 subjects, 28 were tested together with five subjects from the West of Britain families. The four untested subjects comprised two (from one family) whose parents refused screening, one who was being screened at another centre, and one (14 year old) in whom screening was postponed at parental request. Presymptomatic diagnosis was possible with at least one probe in 27 subjects at risk and again the most informative probe was $\pi 227(66 \%)$. Flanking markers were informative in only four of the subjects at risk (table III).

Table IV gives the risk before and after analysis in 
TABLE IV - Risk before and after DNA analysis and indirect ophthalmoscopy in subjects born with 50\% risk of familial adenomatous polyposis

\begin{tabular}{|c|c|c|c|c|c|c|}
\hline Family & Subject & Age & $\begin{array}{l}\text { Risk before } \\
\text { analysis }(\%)\end{array}$ & $\begin{array}{l}\text { Congenital hypertrophy of the } \\
\text { retinal pigment epithelium }\end{array}$ & $\begin{array}{l}\text { Informative } \\
\text { probe }\end{array}$ & $\underset{(\%)}{\text { Combined risk }}$ \\
\hline A & 1 & 35 & 10 & No & YN5.48 & 0.002 \\
\hline \multirow[t]{3}{*}{ B } & 1 & 26 & 15 & No & $\pi 227$, YN5.48 & 0.003 \\
\hline & 2 & 39 & 5 & No & $\pi 227$ & $0 \cdot 1$ \\
\hline & 3 & 37 & 5 & ND & $\pi 227$ & $0 \cdot 1$ \\
\hline C & 1 & 11 & 50 & ND & $\pi 227, \mathrm{YN} 5.48$ & 0.02 \\
\hline \multirow[t]{2}{*}{ D } & 1 & 20 & 20 & No & $\pi 227$ & $0 \cdot 4$ \\
\hline & 2 & 22 & 22 & No & $\pi 227$ & $0 \cdot 4$ \\
\hline \multirow[t]{8}{*}{$\mathrm{E}$} & 1 & 35 & 10 & No & Cllpll & $\star$ \\
\hline & 2 & 36 & 10 & No & $\pi 227$ & $0 \cdot 2$ \\
\hline & 3 & 37 & 5 & No & $\pi 227$ & 0.04 \\
\hline & 4 & 30 & 10 & No & C1lpll, YN5.48 & $\star$ \\
\hline & 5 & 18 & 50 & No & $\pi 227$, YN5.48 & $0 \cdot 002$ \\
\hline & 6 & 16 & 50 & No & $\pi 227$ & 2 \\
\hline & 7 & 11 & 50 & No & $\pi 227$ & 2 \\
\hline & 8 & 9 & 50 & Yes & $\pi 227$ & 98 \\
\hline \multirow[t]{3}{*}{$\mathrm{F}$} & 1 & 22 & 20 & No & $\pi 227$ & $\star$ \\
\hline & 2 & 18 & 40 & No & $\pi 227$ & 0.5 \\
\hline & 3 & 18 & 40 & No & $\pi 227$ & 0.5 \\
\hline \multirow[t]{3}{*}{ G } & 1 & $\geqslant 50$ & 1 & ND & $\pi 227$ & $0 \cdot 1$ \\
\hline & 2 & 15 & 50 & No & None & 16 \\
\hline & 3 & 13 & 50 & No & None & 16 \\
\hline \multirow[t]{2}{*}{$\mathrm{H}$} & 1 & 31 & 30 & No & ECB27 & $0 \cdot 2$ \\
\hline & 2 & 27 & 30 & No & ECB27 & $0 \cdot 2$ \\
\hline I & 1 & 24 & 50 & ND & ECB27 & 3 \\
\hline \multirow{2}{*}{ J } & 1 & 13 & 50 & ND & Cllpll & 5 \\
\hline & 2 & 11 & 50 & ND & C1lpll & 5 \\
\hline \multirow[t]{2}{*}{$\mathrm{K}$} & 1 & 28 & 10 & ND & $\pi 227, \mathrm{C} 11 \mathrm{pll}$ & 0.5 \\
\hline & 2 & 24 & 15 & ND & $\pi 227, \mathrm{C} 1 \mathrm{lpll}$ & 0.8 \\
\hline \multirow[t]{3}{*}{ L } & 1 & 33 & 5 & No & $\pi 227, \mathrm{C} 11 \mathrm{p} 11$ & $0 \cdot 1$ \\
\hline & 2 & 30 & 5 & No & $\pi 227, \mathrm{Cllp} 1 \mathrm{l}$ & $0 \cdot 1$ \\
\hline & 3 & 61 & 1 & ND & $\pi 227, \mathrm{C} 11 \mathrm{p} 11$ & 0.05 \\
\hline \multirow[t]{2}{*}{$M$} & 1 & 17 & 50 & ND & YN5.48 & $0 \cdot 1$ \\
\hline & 2 & 14 & 50 & ND & YN5.48 & 98 \\
\hline
\end{tabular}

$\mathrm{ND}=$ Not done

$\star=$ See text.

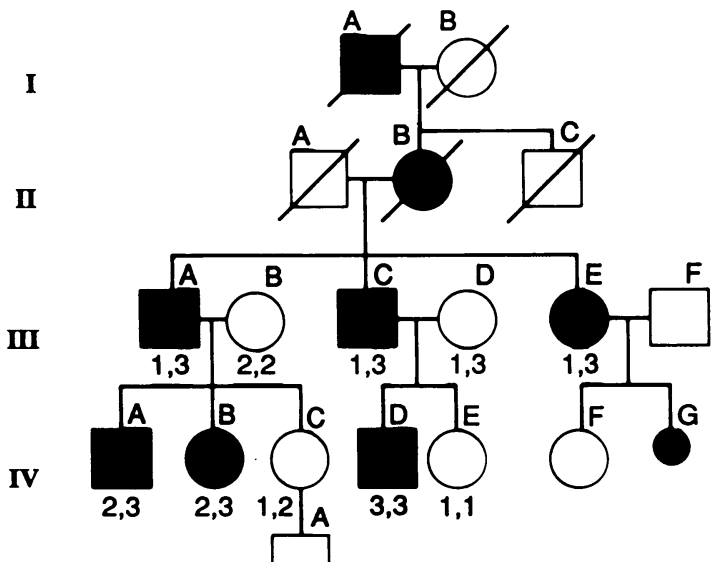

$\mathbf{v}$

FIG 1-Family tree of family showing the $\pi 227 / B c 11$ polymorphism. Alleles are indicated under each person tested

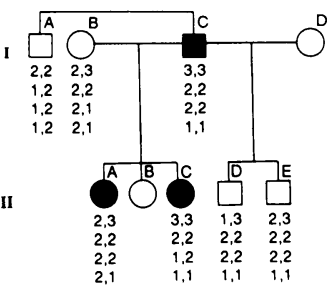

FIG 2-Pedigree of family with familial adenomatous polyposis showing results for four probes, showing results for four probes, $Y N 5.48$, in descending order under each person tested

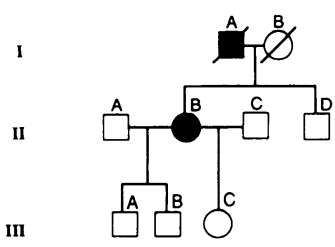

FIG 3-Example of family in which DNA analysis was not possible showed the presence of adenomatous polyps throughout the colon. Only C11p11 was informative for El. Up to May 1991 he had shown no evidence of colonic polyps. Two further definite recombination events were seen in this study, both occurring at a site between $\pi 227$ and the APC gene.

The figures show examples of three families in whom DNA testing proved of value (fig 1), of no value (fig 2) and impossible to perform (fig 3 ). Figure 1 shows a family in whom $\pi 227$ was fully informative. The disease in this family segregates with allele 3 so in the two people at risk (IV-C and IV-E) the risk is independently reduced to $10 \%$ on the basis of the DNA results. As neither IV-C nor IV-E had congenital hypertrophy of the retinal pigment epithelium and both had negative results on recent sigmoidoscopy, the combined risk that these two people will be affected, is less than $1 \%{ }^{16}$ By contrast, in figure 2 the two people at risk (II-D and II-E) remain at 50\% risk as their affected father (I-C) was homozygous for all probes and no member of the family had any evidence of congenital hypertrophy of the retinal pigment epithelium. In figure 3 no DNA testing could be carried out because the key affected family members had died before storage of DNA.

\section{Discussion}

Several studies have shown the potential value of probes linked to the APC gene for presymptomatic diagnosis of familial adenomatous polyposis. ${ }^{11}$ Our study highlighted several practical problems which limit DNA analysis for predictive diagnosis in all affected families, some of which do not seem to have been considered before. In particular we found that DNA testing was impossible in over half of the families with familial adenomatous polyposis, either because the disease was caused by a new mutation or because relevant affected family members were dead.

Even with increasingly early surgical intervention and more rigorous screening protocols, early death from colorectal cancer still occurs. As a consequence only $35 \%$ of our families were suitable for linkage analysis. These families included $46 \%$ (74/162, table II) of the population at risk. In an effort to apply DNA analysis to those families in which key members are dead, we are currently investigating methods of extracting DNA from formalin fixed paraffin embedded tissues which can be analysed for polymorphisms detectable by the polymerase chain reaction. ${ }^{17}$ This technique is useful when only small amounts of damaged DNA are available for analysis and could double the number of families in our register for whom DNA analysis may be diagnostic.

Linkage analysis cannot be done in families in which the disease is caused by a new mutation. The recent identification of the APC gene ${ }^{18-21}$ means that it is now potentially feasible to investigate these families for mutations. However, since most mutations in this gene are different from each other this type of analysis is unlikely to be carried out as a routine diagnostic procedure for all families.

Many probes linked to the APC gene have been identified, some of which show very low recombination between the probe and the gene. ${ }^{910}$ However, we found that the closest probes were relatively uninformative in our population. The most informative probe was $\pi 227$, which unfortunately shows the highest recombination with the APC gene. Flanking markers have previously been reported to be informative in up to $68 \%$ of subjects at risk, ${ }^{9}$ but they were informative in only $12 \%$ of our subjects born with $50 \%$ risk. This is lower than expected based on the relatively high polymorphism information content reported for YN5.48, ${ }^{11}$ this figure being a measure of the usefulness of a genetic marker. Our result is, however, in keeping with another recent study. ${ }^{22}$ Three further probes close to the APC gene have recently been identified ${ }^{1123}$ and may be informative in more families, although two of these, EF5.44 and

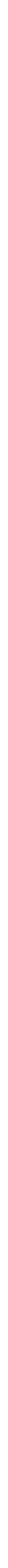


L5.62, have low polymorphism information contents. The characteristation of the APC gene has also identifed several intragenic and closely linked polymorphisms, ${ }^{20}$ which should further increase the accuracy of predictive diagnosis in families with suitable pedigrees. Despite the limitations of the probes we used, DNA analysis enabled alteration of the estimation of risk in $94 \%$ of subjects at risk who were tested. Presence or absence of congenital hypertrophy of the retinal pigment epithelium can be used to alter this estimate further.

In linkage analysis the possibility of genetic heterogeneity must always be considered. This is the possibility that a mutation in two different genes can give rise to the same clinical phenotype. The number of families with familial adenomatous polyposis studied worldwide is still relatively small, and although as yet there is no evidence of genetic heterogeneity, it cannot be ruled out. ${ }^{17}$ For example, in adult polycystic kidney disease there was no initial evidence of heterogeneity, but after five years of using probes linked to the PKD1 locus for presymptomatic diagnosis, evidence for a second locus has been found. ${ }^{24}$ Therefore bowel screening should not be stopped completely, even in people predicted to be at very low risk based on DNA results. Instead, additonal tests are needed that can be used to complement the DNA studies.

At the present time, a combined approach to the investigation of affected families would seem to be most appropriate. This approach includes the notification of families to a register, sigmoidoscopy as appropriate, examination by indirect ophthalmoscopy for congenital hypertrophy of retinal pigment epithelium, identification of other extra colonic signs, and family studies with DNA probes. At this time we would advocate using predictive diagnosis only once bowel screenng has been started. However, now that the APC gene has been identified, the future possibility of presymptomatic interventional therapy may alter this approach.

An integrated approach to screening families with familial adenomatous polyposis is now available. This enables high risk family members to be identified and encouraged to attend for frequent bowel screening. Less frequent screening can be offered to those found to be at low risk. This should help to improve compliance with bowel screening and so further reduce the incidence of colorectal cancer in these families.

\footnotetext{
1 Reed TE, Neale JV. A genetic study of multiple polyposis of the colon. Am $\mathcal{F}$ Hum Genet 1955;7:236-63.

2 Bulow S. Familial polyposis coli. Dan Med Bull 1987;34:1-15.

3 Bussey HJR. Familial polyposis coli: family studies, histopathology, differential diagnosis, and results of treatment. Baltimore: Johns Hopkins University Press, 1975.

4 Chapman PD, Church W, Burn J, Gunn A. Congenital hypertrophy of the retinal pigment epithelium: a sign of familial adenomatous polyposis. $B M \mathcal{J}$ 1989;298:353-4

5 Leppert $M$, Dobbs $M$, Scrambler P, O'Connell P, Nakamura Y, Stauffer D, $e t$ $a l$. The gene for familial adenomatous polyposis maps to the long arm of chromosome 5. Science 1987;238:1411-3.

6 Bodmer WF, Bailey CJ, Bodmer J, Bussey H, Ellis A, Gorman P, et al. Localisation of the gene for familial adenomatous polyposis on chromosome

5. Nature 1987;328:614-6.
7 Meera Khan P, Tops CMJ, van de Broek M, Breukel C, Wijnen JT, Oldenburg M, et al. Close linkage of a highly polymorphic marker (D5S37) to familial adenomatous polyposis (FAP) and cofirmation of FAP localisation to familial adenomatous polyposis (FAP) and cofirmation
on chromosome $5 \mathrm{q} 21-22$. Hum Genet $1988 ; 79: 183-5$.

8 Nakamura Y, Lathrop M, Leppert M, Dobbs M, Wasmuth J, Wolff E, et al. Localisation of the genetic defect in familial adenomatous polyposis within a small region of chromosome 5. Am f Hum Genet 1988;43:638-4

9 Dunlop MG, Wyllie AH, Nakamura Y, Steel CM, Evans HJ, Bird CC. Genetic linkage map around the gene for familial adenomatous polyposis on chromosome 5. Am J Hum Genet 1990;47:982-7.

10 Tops CMJ, Wijnen JT, Griffioen G, van Leeuwen IS, Vasen HFA, den
}

\section{Glossary}

Polymorphic markers-Markers (for example C1lp11) that recognise fragments of variable size. At least two alleles of the marker should be present in the population to be useful.

Penetrance-Probability that a disease genotype will result in an abnormal phenotype.

Centromere-Constricted region of chromosome including site of attachment to spindle.

Telomere-Natural end of the chromosome.

Flanking markers-Two markers, one located on telomeric side and the other on the centromeric side of a gene.

Linkage-Inheritance of two or more markers as a single unit because of their close proximity on the chromosome and not because of chance.

Polymerase chain reaction-Method of amplifying a specific region of DNA so that it can be analysed. In principle the reaction can be performed starting from a single molecule of DNA.

Polymorphism information content-A figure which indicates the usefulness of a polymorphic DNA marker-for example, a PIC of 0.45 means that the probe would be informative in $45 \%$ of families.

Hypervariable probes-Probes which recognise several different alleles and are therefore likely to be highly informative since the variation between individuals is high.

Restriction fragment length polymorphism - Variation in size of DNA fragments produced by restriction endonuclease digestion due to variation in DNA sequence at the enzyme recognition site.

Hartog Jager FCA, et al Presymptomatic diagnosis of familial adenomatou polyposis by bridging DNA markers. Lancet 1989;ii:1361-3.

11 Dunlop MG, Wyllie AH, Steel CM, Piris J, Evans HJ. Linked DNA marker for presymptomatic diagnosis of familial adenomatous polyposis. Lance 1991;337:313-6.

12 Solomon E. Colorectal cancer genes. Nature 1990;343:412-3.

3 Murday V, Slack J. Inherited disorders associated with colorectal cancer Cancer Surv 1989;8:139-57.

14 Sambrook J, Fritsch EF, Maniatis T. Molecular cloning. A laboratory manual. Cold Spring Harbor: Cold Spring Harbor Laboratory Press, 1989.

15 Feinberg A, Vogelstein B. A technique for radiolabelling DNA restriction endonuclease fragments to high specific activity. Anal Biochem 1984;137 266-7.

16 Burn J, Church W, Chapman PD, Gunn A, Delhanty J, Roberts DF. A regional register for familial adenomatous polyposis: congenital hypertrophy of the retinal pigment epithelium as a means of carrier detection. $\mathcal{F}$ Med Genet 1989;26:207.

17 Tops CMJ, Breukel C, van der Klift HM, van Leeuwen ISJ, Wijnen JT, Griffioen $\mathrm{G}$, et al. A new deletion polymorphism at D5S71 raises the linkage information on adenomatous polyposis coli: implications for presymptomatic diagnosis. Hum Genet 1991;86:365-8.

18 Kinzler KW, Nilbert MC, Su LK, Vogelstein B, Brayan TM, Levy DB, et al. Identification of FAP locus genes from chromosome 5q21. Science 1991;253 $661-5$.

19 Nishisho I, Nakamura Y, Miyoshi Y, Miki Y, Ando H, Horii A, et al. Mutations of chromosome $5 \mathrm{q} 21$ genes in FAP and colorectal cancer patients. Science 1991;253:665-9.

20 Groden J, Thliveris A, Samowitz W, Carlson M, Gelbert L, Albertsen H, et al. Identification and characterisation of the familial adenomatous polyposis coli gene. Cell 1991;66:589-600.

21 Joslyn G, Carlson M, Thliveris A, Albertsen H, Groden J, Stevens J, et al. Identification of deletion mutations and three new genes at the familia polyposis locus. Cell 1991;66:601-13.

22 Cachon-Gonzalez MB, Delhanty JDA, Burn J, Tsioupra K, Davis MB, Attwood J, et al. Linkage analysis in adenomatous polyposis coli: the use of four closely linked DNA probes in 20 UK families. 7 Med Gene 991;28:681-5.

23 Breukel C, Tops C, Ras E, Meera Khan P. Mspl RFLP at the D5S122 locus tightly linked to APC. Nucleic Acid Research 1991;19:685.

24 Romeo G, Devoto M, Costa G, Roncuzzi L, Catizone L, Zucchelli P, et al. A second genetic locus for autosomal dominant polycystic kidney disease Lancet 1986;ii:8-10.

(Accepted 3.January 1992) 